\title{
Price Discovery and Co-Integration Analysis between Spot and Futures Prices of Refined Soy Oil in India
}

\author{
Ravindra Singh Shekhawat*, K.N. Singh, Achal Lama and Bishal Gurung \\ ICAR-Indian Agricultural Statistics Research Institute, New Delhi, India \\ *Corresponding author
}

\begin{tabular}{|l|}
\hline Ke y w o r d s \\
Co-integration, Spot \\
prices, Futures \\
prices, Causality, \\
Price discovery \\
\hline Article Info \\
\hline $\begin{array}{l}\text { Accepted: } \\
\text { 04 October } 2018 \\
\text { Available Online: } \\
10 \text { November } 2018\end{array}$ \\
\hline
\end{tabular}

\section{A B S T R A C T}

Futures market is one to mitigate the risk of prices. There is a more important question to know regarding prices, both spot and futures, whether spot affects futures prices or viceversa. The present study examined the co-integration between spot and futures prices of agricultural commodities. The daily spot and futures price data of refined soy oil were obtained from the website of National Commodity and Derivative Exchange (NCDEX), Mumbai. Augmented Dickey-Fuller (ADF) unit root test, Johansen's co-integration test and Vector Error Correction Mechanism (VECM) model were used to achieve the objectives of the study. Major findings of the study revealed that, the results of the Augmented Dickey-Fuller (ADF) unit root test for refined soy oil showed that the level data were non-stationary but their first differences were stationary. This implies the presence of unit root in the spot and futures price series of all the commodities. Hence, both the series were integrated of the order 1 i.e. I (1). Further, the Johansen's cointegration test revealed that the spot and futures prices series were co-integrated. The results of vector error correction mechanism (VECM) showed that the causality of refined soy oil were bi-directional i.e. both spot and futures prices influenced each other equally and hence efficient price discovery.

\section{Introduction}

A central problem of agricultural markets in India has been price instability which has a negative impact on economic growth, income distribution, and on the poverty (Srikanth and Rani, 2007). The uncertainty of commodity prices leaves a farmer open to the risk of receiving a price lower than the expected price for his farm produce. Globally, futures contracts have occupied a very important place to cope this price risk. Futures contracts are originally developed as new financial instrument for price discovery and risk transfer. Changing economic environment, increasing commodity uses through valueaddition at different stages, increasing number of market participants, changing demand and supply position of agricultural commodities and growing international competition requires wider roles for futures markets in the agricultural economy. While well-developed spot markets are sine qua none to a welldeveloped market system, the presence of futures markets on an electronic trading platform does at least in theory gives 
immediate benefits (Srikanth and Rani, 2007). Futures trading perform two important functions of price discovery and risk management with reference to the given commodity. It is useful to all segments of the economy. It is useful to producer because he can get an idea of the price likely to prevail at a future point of time and therefore can decide between various competing commodities, the best suits him. Farmers can derive benefit from futures markets by participating directly/indirectly in the market to hedge their price risks and to take benefit of prices discovered on the platform of commodity exchanges by taking rational and well informed cropping/marketing decisions (Anonymous, 2008). The true measure of price discovery function lies in the extent of the reliability of the futures price as reference price for futures sales and purchases in the physical markets. The greater is, such use of futures price as reference price by the physical market functionaries, stronger will be the correlation between the prices in the physical and futures markets. The high correlation, in turn, ensures the efficacy of the futures markets for price risk management. It also facilitates stocking and production planning for the various market functionaries. Hence, providing a vital tool to the policymakers and planners in designing their pricing policies and investment plans for efficient allocation of resources in different farm sectors and infrastructure (Pavaskar, 2009).

There is a more important question to know regarding prices, both spot and futures, whether spot affects futures prices or viceversa and it is also important to know efficiency of price discovery in both spot and futures prices along with their co-integration.

\section{Materials and Methods}

The study was conducted on secondary data. The daily spot and futures prices refined soy oil were obtained from the website of NCDEX, Mumbai, from 2004 to 2012 as continuous series available.

Refined soy oil was chosen for the purpose of study because, again it is very important from domestic consumption as well as futures trading point of view. Refined soy oil has maximum value of trade among all the edible oils in NCDEX. It has 613.02 lakh tonnes by volume which has value of 402028.75 Rs. Crore up to January 2012 in last financial year 2011-12. Delivery center of soy oil is Indore (M.P.).

\section{Analytical framework}

The Johansen co-integration technique was employed in the present study to analyse the long and short run relationship between cash/spot price and futures price. The main concept of co-integration analysis is that prices move from time to time, and their margins are subject to various shocks that may drive them apart or not. If in the long run they exhibit a linear constant relation, then we say that they are co-integrated. If a set of variable are co-integrated, then there exists a valid error correction representation of the data and these dynamics of short-run prices responses were examined by using Vector Error Correction Mechanism (VECM).

The necessary condition for co-integration is the stationarity of time series data. The time series is stationary when its mean and variance are same in two periods that means all these statistics are independent of time. That means for the stationary time series data, mean value and variance/co-variance does not vary systematically. In order to avoid the spurious or non- sense regression, it is necessary to test the time series data for stationarity. In this study, Augmented Dickey Fuller unit root test was used to test the stationarity which is as follows: 
$\Delta \mathrm{Y}_{\mathrm{t}}=\beta_{1}+\beta_{2} \mathrm{t}+\delta \mathrm{Y}_{\mathrm{t}-1}+\Sigma \alpha_{\mathrm{i}} \Delta \mathrm{Y}_{\mathrm{t}-\mathrm{i}}+\varepsilon_{\mathrm{t}}$

Where,

$\mathrm{Y}_{\mathrm{t}}=$ vector to be tested for co-integration

$\Delta \mathrm{Y}_{\mathrm{t}-1}=\left(\mathrm{Y}_{\mathrm{t}-1}-\mathrm{Y}_{\mathrm{t}-2}\right)$,

$\Delta \mathrm{Y}_{\mathrm{t}-2}=\left(\mathrm{Y}_{\mathrm{t}-2}-\mathrm{Y}_{\mathrm{t}-3}\right)$ etc.

$\varepsilon_{\mathrm{t}}=$ pure white noise error term

The ADF test static follows Tau statistics (Gujarati, 2004).

The number of lagged difference terms included should be enough so that error term in the equation is serially uncorrelated.

$\mathrm{H}_{0}: \delta=0$ (non-stationary)

$\mathrm{H}_{\mathrm{A}}: \delta<0$ (stationary)

The regression of non-stationary time series on another non-stationary time series may produce a spurious regression. Hence, cointegration treatment is given to variables, which are transformed to stationary form.

The two series of price, i.e. spot and futures are individually subjected to unit root analysis. Both are of the order of co-integration one, i.e. the series is transformed into stationary series after differencing once. On regressing the spot price series on futures price series, the error term is subject to unit root analysis.

The Johansen's test based on the errorcorrection representation is as follows:

$\Delta \mathrm{z}_{\mathrm{t}}=\varphi_{\mathrm{k}} \Delta \mathrm{z}_{\mathrm{t}-\mathrm{k}}+\pi \mathrm{z}_{\mathrm{t}-1}+\mu+\varepsilon_{\mathrm{t}}(2)$

Where, $\mathrm{z}_{\mathrm{t}}$ is $\mathrm{n}^{*} 1$ vector of $\mathrm{I}(1)$ processes (price of $n$ market). The rank of $\pi$ equals the number of co-integrating vectors, which is tested by maximum Eigen value and likelihood ratio test statistics. $\mu$ is a constant term has been used to capture the left out variables. The number of lags used in the model was decided on the basis of Akaike Information Criterion (AIC).
In the study Johansen's trace test was used. This test is based on the log-likelihood ratio $\ln \left[L_{\max }(r) / L_{\max }(k)\right], \quad$ and is conducted sequentially for $r=k-1, \ldots, 1,0$. The name comes from the fact that the test statistic involved is the trace (= the sum of the diagonal elements) of a diagonal matrix of generalized Eigen values. This test examines the null hypothesis that the co-integration rank is equal to $r$ against the alternative that the cointegration rank is $k$. The latter implies that $X_{t}$ is trend stationary.

The error correction model was used to estimate the acceleration speed of short-run deviation to long run equilibrium. The error correction model is-

$\Delta \mathrm{S}_{\mathrm{t}}=\theta_{0}+\theta_{1} \Delta \mathrm{S}_{\mathrm{t}-1}+\theta_{2} \Delta \mathrm{F}_{\mathrm{t}-1}+\theta_{3} \mathrm{e}_{\mathrm{t}-1}+\mu_{\mathrm{t}}(3)$

Where,

$\Delta$ denotes first difference operator $\mu_{\mathrm{t}}$ is the random error term

$\mathrm{e}_{\mathrm{t}-1}=\left(\mathrm{S}_{\mathrm{t}}-\alpha-\beta \mathrm{F}_{\mathrm{t}-1}\right)$ that is the one period lagged value of the error from the co integrating regression. Of particular interest is the coefficient of the error correction term, $\theta_{3}$ that indicates the speed at which the series returns to equilibrium.

For value of $\theta_{3}$ that is negative (positive) and less than (equal to) zero, the series converges to (or diverges from) the long run equilibrium. Here $S_{t}$ and $F_{t}$ are spot and futures prices respectively.

\section{Results and Discussion}

In this study, Johansen co-integration and vector error-correction methodology was used to explore the causal relationship and its direction(s) between the spot and futures markets. The analysis consists of following steps: 
Testing for a unit root, I (1), in each series.

Testing for the number of co-integrating vectors in the system.

Estimating and testing for the co-integrating relationship in the framework of a Vector Error Correction Mechanism (VECM).

The unit root test for all the commodities was done using the Augmented Dickey-Fuller (ADF) method, the results of which are presented in Table 1. Then, the co-integration and error correction analysis was conducted whose results are presented in Table 2 and 3.

Table 1 contains the results of the Augmented Dickey-Fuller (ADF) unit root test which show that level data were non-stationary but their first differences were stationary (i.e. implying the presence of unit roots in the series). Thus, the price series of spot and futures markets have a unit root. The occurrence of unit root in the price data generation process of these commodities gave a preliminary indication of shocks which may have permanent or long-lasting effect. Ali (2009) also obtained similar results while studying the performance of commodity markets for pulses in India.

The results of trace test presented in Table 2 for refined soy oil revealed that trace statistic value 295.7271 was greater than the critical value 15.49471 at 5 percent level of significance. This showed the existence of the at least one co-integrating equation(s) at the 5 percent level of significance. This indicated that the model variables had a long-run equilibrium / co-movement among the spot and futures price series during the period under study. The existence of co-integration is necessary for long-term market efficiency. It helps to determine whether spot prices are affected by the futures prices or not.

Table.1 ADF unit root test for spot and futures prices of selected agricultural commodities

\begin{tabular}{|l|c|c|}
\hline \multicolumn{1}{|c|}{ Commodities } & \multicolumn{2}{c|}{ Augmented Dickey-Fuller (ADF) } \\
\hline Refined Soy Oil & Level & $\mathbf{1}^{\text {st }}$ difference \\
\hline Spot price & $-0.550913(0.8786)$ & $-34.41875^{*}(0.000)$ \\
\hline Futures price & $-1.006876(0.7528)$ & $-7.883951^{*}(0.000)$ \\
\hline
\end{tabular}

"significant at $1 \%$ level

Note: Figures in parentheses indicate Mackinnon (1996) one sided p-values.

Table.2 Johansen co-integration test for refined soy oil

\begin{tabular}{|c|c|c|c|c|}
\hline \multicolumn{5}{|c|}{ Unrestricted Co-integration Rank Test (Trace) } \\
\hline $\begin{array}{l}\text { Hypothesized } \\
\text { No. of CE(s) }\end{array}$ & Eigen value & Trace Statistic & $\begin{array}{c}0.05 \\
\text { Critical Value }\end{array}$ & Prob.** \\
\hline None * & 0.137128 & 295.7271 & 15.49471 & 0.0001 \\
\hline At most 1 & 0.000374 & 0.748284 & 3.841466 & 0.3870 \\
\hline \multicolumn{5}{|c|}{ Trace test indicates 1 co-integrating eqn (s) at the 0.05 level } \\
\hline \multicolumn{5}{|c|}{ * denotes rejection of the hypothesis at the 0.05 level } \\
\hline
\end{tabular}


Table.3 Vector Error Correction Mechanism (VECM) estimates for refined soy oil

\begin{tabular}{|c|c|c|}
\hline \multicolumn{3}{|c|}{ Standard errors in ()$\&$ t-statistics in [ ] } \\
\hline Co-integrating Eq: & CointEq1 & \\
\hline $\mathrm{SS}(-1)$ & 1.000000 & \\
\hline \multirow[t]{3}{*}{$\mathrm{FF}(-1)$} & -1.002533 & \\
\hline & $(0.00497)$ & \\
\hline & [-201.674] & \\
\hline $\mathrm{C}$ & 1.693507 & \\
\hline Error Correction: & $\mathrm{D}(\mathrm{SS})$ & $\mathrm{D}(\mathrm{FF})$ \\
\hline \multirow[t]{3}{*}{ CointEq1 } & $-0.093182^{*}$ & $0.035555^{*}$ \\
\hline & $(0.01759)$ & $(0.00270)$ \\
\hline & {$[-5.29704]$} & [ 13.1554] \\
\hline \multirow[t]{3}{*}{$\mathrm{D}[\mathrm{SS}(-1)]$} & $0.155235^{*}$ & 0.005415 \\
\hline & $(0.02535)$ & $(0.00389)$ \\
\hline & [ 6.12314] & [ 1.39014] \\
\hline \multirow[t]{3}{*}{$\mathrm{D}[\mathrm{SS}(-2)]$} & $-0.099685^{*}$ & $-0.009461^{*:}$ \\
\hline & $(0.02471)$ & $(0.00380)$ \\
\hline & {$[-4.03376]$} & [-2.49195] \\
\hline \multirow[t]{3}{*}{$\mathrm{D}[\mathrm{FF}(-1)]$} & $0.504802^{*}$ & $0.389329^{*}$ \\
\hline & $(0.14325)$ & $(0.02201)$ \\
\hline & [ 3.52382] & [ 17.6896] \\
\hline \multirow[t]{3}{*}{$\mathrm{D}[\mathrm{FF}(-2)]$} & 0.057996 & $0.337964^{*}$ \\
\hline & $(0.13500)$ & $(0.02074)$ \\
\hline & [ 0.42961] & [ 16.2952] \\
\hline \multirow[t]{3}{*}{$\mathrm{C}$} & 0.036509 & 0.028237 \\
\hline & $(0.12572)$ & $(0.01932)$ \\
\hline & [ 0.29039] & [ 1.46187] \\
\hline R-squared & 0.047741 & 0.730265 \\
\hline Adj. R-squared & 0.045353 & 0.729588 \\
\hline Sum sq. resids & 62453.73 & 1474.146 \\
\hline S.E. equation & 5.596501 & 0.859820 \\
\hline F-statistic & 19.99349 & 1079.687 \\
\hline Log likelihood & -6279.156 & -2532.809 \\
\hline Akaike AIC & 6.285156 & 2.538809 \\
\hline Schwarz SC & 6.301959 & 2.555611 \\
\hline Mean dependent & 0.101375 & 0.104500 \\
\hline S.D. dependent & 5.727897 & 1.653465 \\
\hline \multicolumn{2}{|c|}{ Determinant resid covariance (dof adj.) } & 19.00677 \\
\hline \multicolumn{2}{|l|}{ Log likelihood } & -8614.540 \\
\hline \multicolumn{2}{|l|}{ Akaike information criterion } & 8.628540 \\
\hline \multicolumn{2}{|l|}{ Schwarz criterion } & 8.667747 \\
\hline
\end{tabular}


Table 3, shows the results of VECMs between spot and futures prices. The size of error correction in spot prices $(-0.093)$ is negative and highly significant at 1 percent level of significance, implies that decrease in the previews period's equilibrium error leads to a decrease in current period spot price. Whereas the size of error correction in the futures prices (0.036) is positive and highly significant at 1 percent level of significance, implies that increase in the previews period's equilibrium error leads to an increase in current period spot price. Both the error correction coefficient suggests that a sustainable long-term equilibrium is achieved by closing the gap between futures and spot prices. In other words, future price rise to meet increase in spot prices while spot prices revert to futures prices.

The error correction coefficient in spot and futures is -0.093 and 0.036 respectively. This measures how quickly the dependent variables, such as, spot and futures prices absorb and adjust themselves for last period disequilibrium errors. In other words, it measures the ability of dependent variable, such as, spot and futures prices to incorporate shocks or news in its prices. As per the results, spots and futures absorb 9.3 and 3.6 percent respectively. Spot news incorporation is marginally higher than futures. Result suggests that presence of spot market leads marginally price discovery process.

As regard short run causality, that is changes in futures (spot) prices with respect to lagged changes in spot (futures). In the spot price model of refined soy oil, the coefficient of 1 day lagged futures price was positive $(0.505)$ and highly significant at 1 percent level of significance. It implies that price discovery was occurred futures market and was transmitted to spot market. The coefficient of its own (spot) 1 day lagged spot price was positive (0.155) and highly significant at 1 percent level of significance and 2 day's lagged spot price was negative (-0.010) and highly significant at 1 percent level of significance. It means that the spot market was influenced by its own price too.

However, the futures model, the coefficient of 2 day's lagged spot price was negative (0.009 ) and significant at 5 percent level of significance. This indicates that price discovery was occurred in the spot market, from where the information flowed to futures market. The coefficient of its own (futures) 1 day lagged (0.389) and 2 day's lagged (0.338) spot prices was positive and highly significant at 1 percent level of significance. It means futures market was influenced by its own price too.

This showed that the causality was bidirectional, due to which it was difficult to determine which market played a key role in discovering the price of refined soy oil.

Co-integration analysis was done by using Eviews software package. It was found that spot and futures prices are co-integrated and influenced to each other, which cause more efficient price discovery but it was very difficult to know which price plays a key role in case of refined soy oil. So both spot and futures prices leads a key role in the price discovery process.

One of the important function of futures trading is efficient price discovery, was revealed clearly in this study. So, it is suggested to promote futures trading, by which farmers can get remunerative price for their produces, which is beneficial to not only farmers but also economy as a whole.

\section{References}

Ali, J. 2009. Performance of Commodity Markets for Pulses in India. Takshashila 
Academia of Economic Research, Pavaskar, M. and Kshirsagar, A. 2009. Mumbai. Pp. 168-182.

Anonymous. 2008. Report of the Expert

Committee to Study the Impact of Futures Trading on Agricultural Commodity Prices, Ministry of Consumer Affairs, Food and Public Distribution, GOI.

Gujarati, D. N. 2004. Time Series Econometrics: Some Basic Concepts. Basic Econometrics (IV Edition), Tata McGraw- Hill Publishing Company Limited, New Delhi. 792-826. Pricing and Marketing efficiency in Cotton and the Need for Risk Management. Takshashila Academia of Economic Research, Mumbai. 52-61.

Srikant, T. and Rani, R. A. 2007. Performance of Commodity futures in India: The Way Ahead. In: Velmurugan, P. S., Palanichamy, P. and Shunmugam, V. eds. Indian Commodity Market (Derivatives and Risk Management). $1^{\text {st }}$ edn. Serials Publications, New Delhi.

www.ncdex.com. Visited on 22- 03- 2012.

\section{How to cite this article:}

Ravindra Singh Shekhawat, K.N. Singh, Achal Lama and Bishal Gurung. 2018. Price Discovery and Co-Integration Analysis between Spot and Futures Prices of Refined Soy Oil in India. Int.J.Curr.Microbiol.App.Sci. 7(11): 40-46. doi: https://doi.org/10.20546/ijcmas.2018.711.007 